\title{
Surgery for Meralgia Paresthetica: Neurolysis Versus Nerve Resection
}

\section{Meralgia Paresthetica İcin Cerrahi: Nöroliz ve Sinir Rezeksiyonu}

\author{
Mohammadreza EMAMHADI \\ Guilan University of Medical Sciences, Department of Neurosurgery, Brachial Plexus and Nerve Injury Center, Rasht, Iran
}

Correspondence address: Mohammadreza EMAMHADI / E-mail: daneshpajouhan@mail.com

\begin{abstract}
AIM: Neurolysis with transposition of the nerve and nerve resection are commonly performed surgical procedures for appropriate managing Meralgia Paresthetica (MP). But long-term outcome of these two procedures are uncertain. This case-series study came to address follow-up results of these two surgical procedures for managing MP.

MATERIAL and METHODS: We prospectively described 14 consecutive non-obese patients with clinical features of MP managed by one of the two studied procedures (nerve resection or neurolysis). Clinical variables were documented for each individual. The outcome of the surgery was assessed in follow-up visits within 18 months after the procedure.

RESULTS: Nine patients were treated with neural resection procedure and others underwent neurolysis technique. In the group that underwent nerve resection, all patients experienced complete relief of unpleasant symptoms and MP did not recur in any of them during follow-up, while all patients who underwent neurolysis reported MP recurrence within 1 to 9 months after treatment initiation.
\end{abstract}

CONCLUSION: Our results demonstrated that nerve resection is superior to neurolysis in terms of recurrence.

KEYWORDS: Meralgia paresthetica, Neurolysis, Nerve resection, Pain, Recurrence

ÖZ

AMAÇ: Sinir rezeksiyonu ve sinir transpozisyonu ile nöroliz Meralgia Paresthetica (MP) uygun tedavisi için sık yapılan cerrahi işlemlerdir. Ancak bu iki işlemin uzun dönemli sonucu halen kesin değildir. Bu vaka çalışmasının amacı, MP takibinde bu iki cerrahi işlemin takip sonuçlarını değerlendirmekti.

YÖNTEM ve GEREÇLER: MP klinik özellikleri olan ve çalışılan iki işlemden (sinir rezeksiyonu veya nöroliz) biriyle takip edilen arka arkaya 14 obez olmayan hastayı prospektif olarak tanımladık. Her birey için klinik değişkenler belgelendirildi. Cerrahi sonucu işlemden sonraki 18 ay içinde takip ziyaretleriyle değerlendirildi.

BULGULAR: On dokuz hasta nöral rezeksiyon işlemiyle tedavi edilirken diğerlerinde nöroliz tekniği kullanıldı. Sinir rezeksiyonu yapılan gruptaki tüm hastalarda hoş olmayan belirtilerin kaybı görüldü ve MP hiçbirinde takip süresinde tekrarlamadı ama nöroliz yapılan dokuz hastanın tümünde tedavinin başlamasından 1-9 ay sonra MP tekrarladı.

SONUÇ: Sonuçlarımız sinir rezeksiyonunun rekürans açısından nörolize üstün olduğunu göstermiştir.

ANAHTAR SÖZCÜKLER: Meralgia paresthetica, Nöroliz, Sinir rezeksiyonu, Ağrı, Rekürans

\section{INTRODUCTION}

Meralgia Paresthetica (MP) is a painful mononeuropathy of the lateral femoral cutaneous nerve (LFCN) commonly due to focal entrapment of this nerve and rarely caused by other etiologies such as trauma, stretch injury, or ischemic events (12). Making its diagnosis is usually based on medical history and clinical examinations as well as confirmed by nerve conduction studies (2). Some potential factors have been also identified as predisposing individuals to this disorder, including diabetes mellitus, pregnancy, obesity, intra-abdominal disease that increases intra-pelvic pressure, certain anatomical variations of the LFCN, and even tight clothing $(10,11,14)$. The best therapeutic approach for MP is removing underlying etiologies and predisposing factors of nerve compression. In most patients with mild symptoms, conservative management seems to be enough $(16,19)$. However, in cases with more severe pain or other limitations such as physical disability, a focal nerve block is programmed routinely with a combination of lidocaine and corticosteroids effective for prolonged periods $(6,18)$. In rare and especially in painful cases that are unresponsive to nerve block, surgical decompression can be warranted $(5,13)$. Neurolysis with transposition or resection of the nerve are the two commonly performed surgical procedures for MP. Which surgical procedure is most effective and which should be attempted first are topics of some debate (1).-On the other hand, the surgical management of MP poses formidable challenges in the clinical settings. Some authors suggest that neurolysis 
is prior to resection because resection results in permanent numbness in the nerve distribution (4). Besides, some others believe that resection might be the only option if the nerve has been severely damaged or if multiple branches are affected. Moreover, the rate of symptom recurrence may be higher with the neurolytic procedures than with resection (20). It generally relieves spontaneously or with minimal conservative interventions. Surgery may be necessary in seldom cases due to its extension and uncontrolled status following conservative approaches. As it has been remained unclear whether neurolysis or resection is the procedure of choice, we evaluated the outcome of two surgical procedures for managing MP.

\section{MATERIAL and METHODS}

We prospectively described 14 consecutive non-obese patients with clinical features of MP referred to the Neurosurgery Department of Poursina Hospital in Rasht, Iran over a period of 8 years (2000 to 2008) managed by one of the two studied procedures (nerve resection or neurolysis). The clinical diagnosis of MP was based on the presence of the following manifestations: 1) unpleasant paresthesias/ numbness/burning sensation/dysesthesias/pain over the anterolateral aspect of the thigh and 2) exacerbation of symptoms on walking, standing, or extending the hips (21). Those with known etiologies of secondary MP such as prior pelvic orthopedic surgery and pelvic trauma were not entered into the study. All patients underwent a detailed neurological examination, and computerized tomography (CT) scan/ magnetic resonance imaging (MRI) was performed to rule out any radicular lesion of the lumbar roots. Furthermore, female patients underwent ultrasound of the pelvis and lower abdomen to rule out a pelvic tumors and masses. The study was approved by the ethics committee of our institution, and written informed consent was obtained from all patients. Clinical variables such as gender, age, duration of symptoms, and location of the involved nerve were documented for each individual preoperatively in the clinic. Each patient was informed about the complication of the procedures and they chose their preferred operative choice.

Under general anesthesia a $3 \mathrm{~cm}$ incision immediately beneath the lateral extent of the inguinal ligament was carried out down to the fascia lata which was incised in the same direction. The nerve was exposed, and pulled down and transected or transposed medially by incising the shelving border of the inguinal ligament (Neurolysis) (Figure 1). In transection, the surgeon should ensure that the proximal portion of the nerve was within the pelvis in order to minimize the formation of a painful neuroma (Figure 2). The wound was closed with sutures and removed a week later. The surgical outcome was assessed in follow-up visits within 18 months after the procedure. Surgical outcome measures were defined as 'complete relief' when the presenting symptoms had completely resolved and recurrence was not appeared and 'incomplete relief' when there was persistence or worsening of the presenting symptoms or recurrence was occurred. For those patients not achieving complete relief, follow-up visits were arranged at approximately 3-month intervals for further assessment. Telephone interviewing was also conducted to assess long-term results if required.

Results were presented as mean \pm standard deviation (SD) for quantitative variables and were summarized by absolute frequencies and percentages for categorical variables. Categorical variables were compared using chi-square test or Fishers exact test when more than $20 \%$ of cells with expected count of less than 5 were observed. Quantitative variables were also compared using $t$ test or Mann-Whitney $U$ test. Survival rate and probability of success were determined by using the Kaplan-Meier method. Statistical significance was determined as a $p$ value of $\geq 0.05$. All statistical analysis was performed using SPSS software (version 16.0, SPSS Inc., Chicago, Illinois).

\section{RESULTS}

Fourteen decompressive procedures (7 left-sided and 7 right-sided) were performed in 7 men and 7 women from 2000 to 2008. The age of the participants ranged between 29 and 65 years with a mean of $46.4 \pm 9.8$ years. The duration of symptoms averaged $18.1 \pm 11.9$ months (range 6 to 48 months). Among these, 9 patients were treated with nerve resection procedure and others underwent neurolysis technique (Table I). Comparing baseline characteristics and clinical data showed no significant differences between the two groups undergoing resection or neurolysis procedures (Table II). Eighteen-month follow-up was completed in all 14 patients. In the nerve resection group, all patients experienced complete relief of unpleasant symptoms and MP did not recur in any of them during the follow-up period. All patients who experienced neurolysis reported MP recurrence within 1 to 9 months after treatment initiating.

Univariate analyses were conducted to determine the significance of age, sex, duration of symptoms, and location of involved nerve on the rate of achieving no recurrence (Table III). Regardless of procedure type, age, sex, duration of symptoms, and involved nerve did not show any significant association with the appearance of MP recurrence (Figure 3).

The calculated successful probability for neurolysis procedure was $2^{-5}(\rho=0.031)$. Beside, the non-successful probability for nerve resection procedure was estimated $2^{-9}(\rho=0.002)$. On the other hand, successful probability for neurolysis was $3.0 \%$ and non-successful probability for nerve resection procedure was $0.2 \%$.

\section{DISCUSSION}

The outcome of MP generally depends on whether diagnosis and therapeutic management are achieved within a reasonable time frame. The prognosis from conservative management alone is quite good because the condition often is self-limited $(20,21)$. In this context, conservative plan have been shown to result in appropriate result because the condition is often self limited. But, in the cases with more 
Table I: Description of Demographics and Clinical Data in Study Patients

\begin{tabular}{|c|c|c|c|c|c|c|c|}
\hline $\begin{array}{l}\text { Patient } \\
\text { No. }\end{array}$ & $\begin{array}{l}\text { Type of } \\
\text { procedure }\end{array}$ & Gender & Age & $\begin{array}{l}\text { Nerve } \\
\text { location }\end{array}$ & $\begin{array}{l}\text { Duration of } \\
\text { symptoms }\end{array}$ & Recurrence & $\begin{array}{c}\text { Time of recurrence } \\
\text { appearance }\end{array}$ \\
\hline 1 & Resection & Male & $45 y$ & Left & $24 \mathrm{mo}$ & No & $0 \mathrm{mo}$ \\
\hline 2 & Resection & Male & $46 y$ & Right & $48 \mathrm{mo}$ & No & $0 \mathrm{mo}$ \\
\hline 3 & Resection & Female & $65 y$ & Right & $14 \mathrm{mo}$ & No & $0 \mathrm{mo}$ \\
\hline 4 & Resection & Male & $38 y$ & Left & $24 \mathrm{mo}$ & No & $0 \mathrm{mo}$ \\
\hline 5 & Resection & Female & $29 y$ & Right & $36 \mathrm{mo}$ & No & $0 \mathrm{mo}$ \\
\hline 6 & Resection & Female & $52 y$ & Left & $14 \mathrm{mo}$ & No & $0 \mathrm{mo}$ \\
\hline 7 & Resection & Female & $58 y$ & Right & $12 \mathrm{mo}$ & No & $0 \mathrm{mo}$ \\
\hline 8 & Resection & Female & $44 y$ & Right & $6 \mathrm{mo}$ & No & $0 \mathrm{mo}$ \\
\hline 9 & Resection & Female & $53 y$ & Right & $9 \mathrm{mo}$ & No & $0 \mathrm{mo}$ \\
\hline 10 & Neurolysis & Male & $56 y$ & Left & $9 \mathrm{mo}$ & Yes & $3 \mathrm{mo}$ \\
\hline 11 & Neurolysis & Male & $33 y$ & Right & $10 \mathrm{mo}$ & Yes & $4 \mathrm{mo}$ \\
\hline 12 & Neurolysis & Female & $41 y$ & Left & $12 \mathrm{mo}$ & Yes & $9 \mathrm{mo}$ \\
\hline 13 & Neurolysis & Male & $43 y$ & Left & $12 \mathrm{mo}$ & Yes & $1 \mathrm{mo}$ \\
\hline 14 & Neurolysis & Male & $46 y$ & Left & $24 \mathrm{mo}$ & Yes & $3 \mathrm{mo}$ \\
\hline
\end{tabular}

Table II: Baseline Characteristics and Clinical Data in the Two Groups Undergoing Neurolysis or Nerve Resection

\begin{tabular}{|c|c|c|c|c|}
\hline Characteristics & Total $(n=14)$ & Nerve resection $(n=9)$ & Neurolysis $(n=5)$ & P-value \\
\hline Gender, n (\%) & & & & 0.266 \\
\hline Male & $7(50.0)$ & $3(33.3)$ & $4(80.0)$ & \\
\hline Female & $7(50.0)$ & $6(66.7)$ & $1(20.0)$ & \\
\hline Age (year), mean/SD & $46.4 \pm 9.8$ & $47.8 \pm 10.7$ & $43.8 \pm 8.3$ & 0.459 \\
\hline Duration of symptoms (month), mean/SD & $18.1 \pm 11.9$ & $20.8 \pm 13.8$ & $13.4 \pm 6.1$ & 0.193 \\
\hline Involved nerve location, n (\%) & & & & 0.266 \\
\hline Left & $7(50.0)$ & $3(33.3)$ & $4(80.0)$ & \\
\hline Right & $7(50.0)$ & $6(66.7)$ & $1(20.0)$ & \\
\hline
\end{tabular}

Table III: Univariate Analysis of the Association between Different Patient Variables and Procedure Outcome

\begin{tabular}{|l|c|c|c|}
\hline Item & Complete relief & Incomplete relief & P-value \\
\hline Gender (male to female) & 3.6 & 4.1 & 0.266 \\
\hline Age (year), mean/SD & $47.8 \pm 10.7$ & $43.8 \pm 8.3$ & 0.459 \\
\hline Duration of symptoms (month), mean/SD & $20.8 \pm 13.8$ & $13.4 \pm 6.1$ & 0.193 \\
\hline Location (left to right) & 3.6 & 4.1 & 0.266
\end{tabular}

disabilities and complains, surgical approaches should be considered; however the efficacy of these procedures is already questioned. The present study showed that regarding pain relief and avoiding MP recurrence, resection approach is completely prior to neurolysis so that among participants who underwent former procedure, all of them experienced complete relief and no symptom recurrence, whereas all patients in neurolysis group suffered from disease recurrence within 9 months after the procedure. On the other hand, resection procedure had acceptable and successful results, but neurolysis had a poor long-term outcome. Some previous studies were in consistent with our survey. Van Eerten et al. (20) noted complete symptom relief in 3 of 10 patients who underwent neurolysis and in 9 of 11 patients who had a resection. Similarly, 23 of 24 patients who had a resection in Williams and Trzil's (21) series had complete relief of their presenting symptoms. Ivins (7) reported results for 8 patients who underwent neurolysis; 4 experienced relief of symptoms, of which 2 had recurrence of their symptoms. Siu (17) reported results from a case series of 45 decompressive procedures in 42 patients who underwent neurolysis: $43 \%$ reported complete relief, $40 \%$ reported partial relief, and $17 \%$ reported no relief. Also, in a study by Kim et al. (8) superior results of resection as a treatment for meralgia paresthetica 


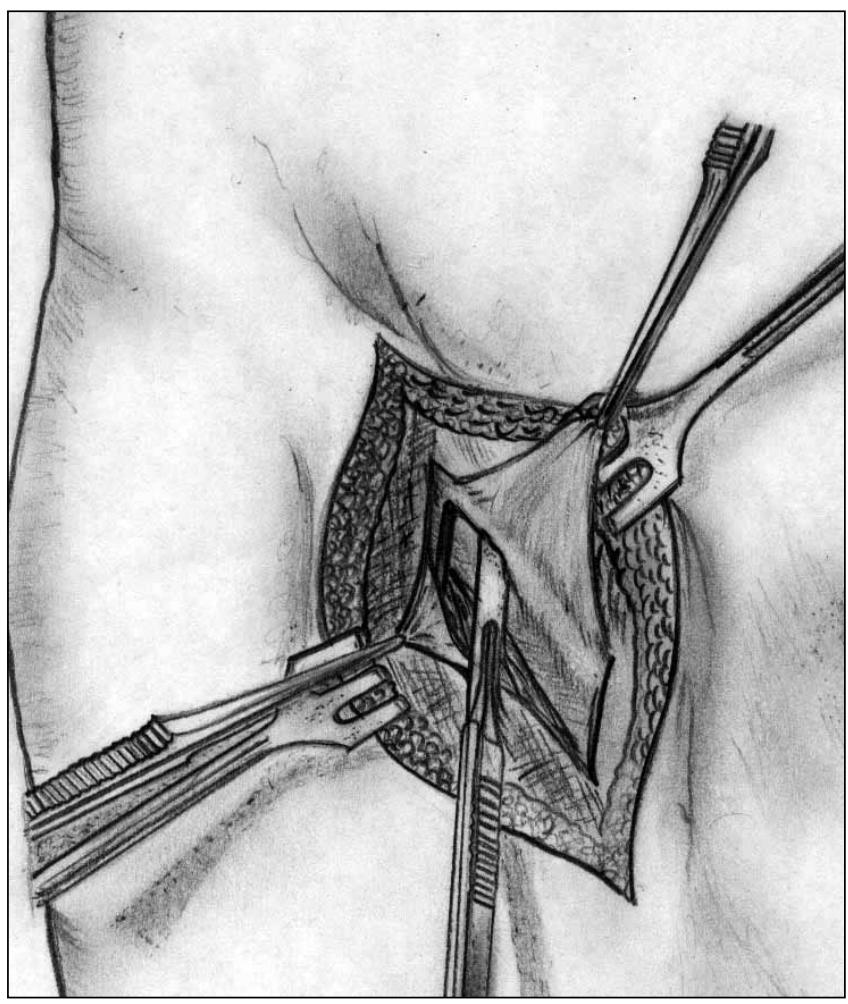

Figure 1: Neurolysis and transposition of lateral femoral cutaneous nerve.

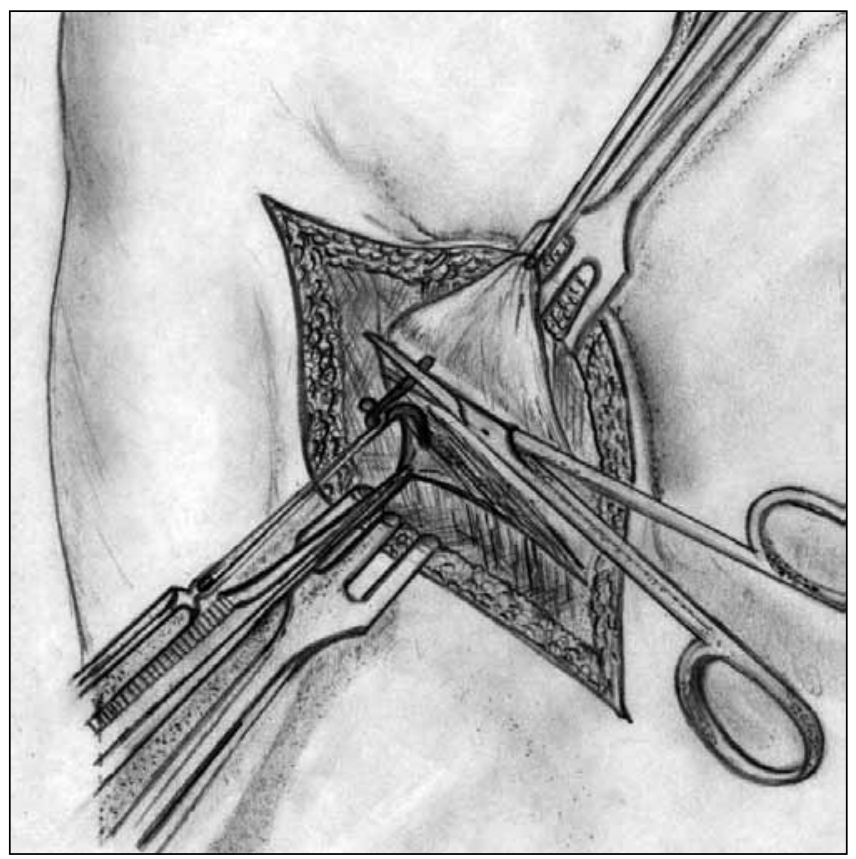

Figure 2: Transection of the nerve.

was obtained. But, there was no statistically significant difference between the two procedures because of small sample size. However, some older studies in the literatures showed that the planning neurolysis could achieve symptoms improvement between $60.0 \%$ and $95.7 \%$ during a follow-up

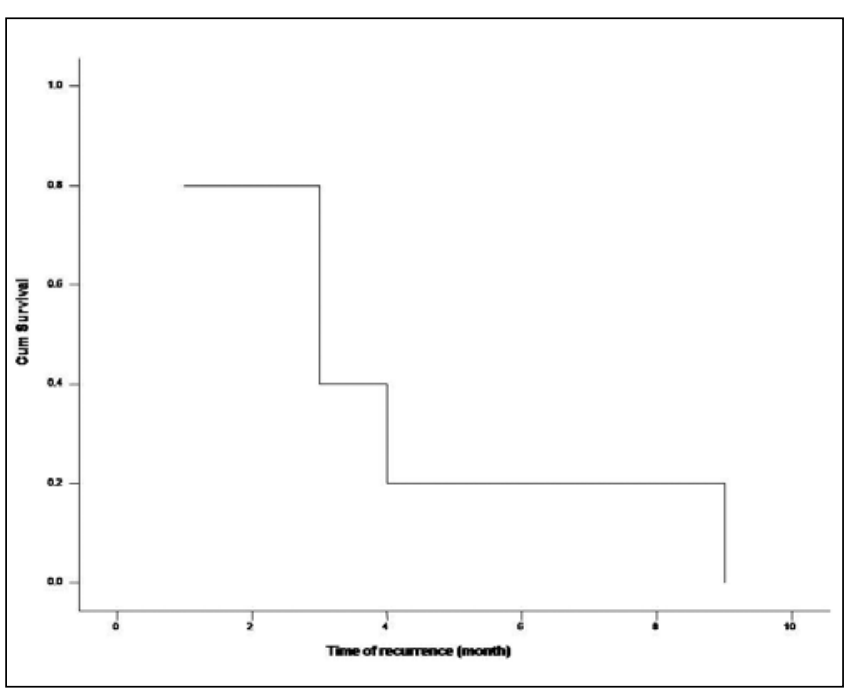

Figure 3: Rate of recurrence in Neurolysis method within followup time.

time ranged 1 to 5.5 years after operation $(3,9,12)$. Totally, it seems that the long-term follow-up of resection procedure demonstrates a favorable surgical outcome of neurolysis for MP compared with neurolysis.

Although resection procedure seems to be prior to other studied operation and is more likely to produce complete relief, but its complications such as permanent anesthesia of the anterolateral thigh, probable motion restriction, postoperative local infection or bleeding, and even worsening of the pain should be considered and prevented. For this aim and before the procedure, the patients should be counseled about this potential risks. Also, surgical site tenderness should be removed with analgesics. Range of motion and function should be assessed after surgery and if disabilities are appeared, rehabilitation sessions should be programmed. Moreover, the treated subject should have thorough neurologic examinations immediately after the procedure and serial examinations for several months afterward to evaluate whether the procedure helped alleviate the symptoms of MP and to identify any complications.

Our univariate outcome analysis of different patient variables had yielded an interesting result in that regardless of the type of therapeutic approach, no significant correlation between baseline indices (demographics, location of diseased nerve, and duration of symptoms) and disease recurrence was observed. In fact, symptoms recurrence can be dependant to other patients' characteristics, intraoperative variables, and early postoperative events that can be assessed using multivariable regression models on grater sample size in further studies.

\section{CONCLUSION}

In conclusion, comparing long-term results of the two procedures, transection and neurolysis, for treatment of MP, shows that former procedure was superior regarding longterm complete symptom relief, with no recurrence. 


\section{ACKNOWLEDGEMENT}

This study was supported by the Guilan University of Medical Sciences. We thank the University authorities who offered critical administrative support and managerial services in carrying out the study and also all researchers for their help and support. There is no conflict of interest.

\section{REFERENCES}

1. Alberti O, Wickboldt J, Becker R: Suprainguinal retroperitoneal approach for the successful surgical treatment of meralgia paresthetica. J Neurosurg 110:768-774, 2009

2. Carai A, Fenu G, Sechi E, Crotti FM, Montella A: Anatomical variability of the lateral femoral cutaneous nerve: Findings from a surgical series. Clin Anat 22:365-370, 2009

3. Edelson R, Stevens P: Meralgia paresthetica in children. J Bone Joint Surg Am 76:993- 999, 1994

4. Grossman MG, Ducey SA, Nadler SS, Levy AS: Meralgia Paresthetica: Diagnosis and Treatment. J Am Acad Orthop Surg 9:336-344, 2001

5. Harney D, Patijn J: Meralgia paresthetica: Diagnosis and management strategies. Pain Med 8:669-677, 2007

6. Hurdle MF, Weingarten TN, Crisostomo RA, Psimos C, Smith J: Ultrasound-guided blockade of the lateral femoral cutaneous nerve: Technical description and review of 10 cases. Arch Phys Med Rehabil 77:1362-1364, 2007

7. Ivins GK: Meralgia paresthetica, the elusive diagnosis: Clinical experience with 14 adult patients. Ann Surg 232:281-286, 2000

8. Kim CG, Kim C: Surgical Results of Meralgia Paresthetica. J Korean Neurosurg Soc 35:188-191, 2004

9. MacNicol MF, Thompson WJ: Idiopathic meralgia paresthetica. Clin Orthod Res 254:270-274, 1990

10. Mondelli M, Rossi S, Romano C: Body mass index in meralgia paresthetica: A case-control study. Acta Neurol Scand 116:118-123, 2007
11. Moucharafieh R, Wehbe J, Maalouf G: Meralgia paresthetica: A result of tight new trendy low cut trousers ('taille basse'). Int J Surg 6:164-168, 2008

12. Nahabedian MY, Dellon AL: Meralgia paresthetica: Etiology, diagnosis and outcome of surgical decompression. Ann Plast Surg 35:590-594, 1995

13. Nouraei SA, Anand B, Spink G, O'Neill KS: A novel approach to the diagnosis and management of meralgia paresthetica. Neurosurgery 60:696-700, 2007

14. Parisi TJ, Mandrekar J, Dyck PJ, Klein CJ: Meralgia paresthetica: Relation to obesity, advanced age, and diabetes mellitus. Neurology 77:1538-1542, 2011

15. Patijn J, Mekhail N, Hayek S, Lataster A, van Kleef $M$, Van Zundert J: Meralgia Paresthetica. Pain Pract 11:302-308, 2011

16. Seror P, Seror R: Meralgia paresthetica: Clinical and electrophysiological diagnosis in 120 cases. Muscle Nerve 33: 650-654, 2006

17. Siu TL, Chandran KN: Neurolysis for meralgia paresthetica: An operative series of 45 cases. Surg Neurol 63:19-23, 2005

18. Tumber PS, Bhatia A, Chan VW: Ultrasound-guided lateral femoral cutaneous nerve block for meralgia paresthetica. Anesth Analg 106:1021-1022, 2008

19. van Slobbe AM, Bohnen AM, Bernsen RM: Incidence rates and determinants in meralgia paresthetica in general practice. $J$ Neurol 251:294-297, 2004

20. van Eerten PV, Polder TW, Broere CA: Operative treatment of meralgia paresthetica: Resection versus neurolysis. Neurosurgery 37:63-65, 1995

21. Williams PH, Trzil KP: Management of meralgia paresthetica. J Neurosurg 74:76-80, 1991 